University of Nebraska - Lincoln

DigitalCommons@University of Nebraska - Lincoln

Faculty Publications, College of Journalism \& Journalism and Mass Communications, College Mass Communications

9-25-1983

\title{
Editorial Patterns of Tribune Under Three Editors
}

John W. Windhauser

Louisiana State University

Will Norton Jr.

University of Nebraska-Lincoln, hwnorton@gmail.com

Sonny Rhodes

Log Cabin Democrat, Conway, Arkansas

Follow this and additional works at: https://digitalcommons.unl.edu/journalismfacpub

Part of the Journalism Studies Commons

Windhauser, John W.; Norton, Will Jr.; and Rhodes, Sonny, "Editorial Patterns of Tribune Under Three Editors" (1983). Faculty Publications, College of Journalism \& Mass Communications. 9. https://digitalcommons.unl.edu/journalismfacpub/9

This Article is brought to you for free and open access by the Journalism and Mass Communications, College of at DigitalCommons@University of Nebraska - Lincoln. It has been accepted for inclusion in Faculty Publications, College of Journalism \& Mass Communications by an authorized administrator of DigitalCommons@University of Nebraska Lincoln. 
Editorial Patterns of Tribune Under Three Editors

By John W. Windhauser, Will Norton, Jr., And Sonny Rhodes

- Until the death of Col. Robert McCormick in 1955, the Chicago Tribune was 
known as a staunch opposition to change, following an editorial policy of ultraconservatism. ${ }^{2}$ During his 45-year tenure, McCormick's distinctive editorial policies and style often ran counter to public opinion, and he kept his positions even when opposition came from his own copy editors. ${ }^{3}$

But, those personal policies, McCormick himself said, would continue with his

I "Major Papers Were Built in McCormick's Press Empire," New York Times, April 1, 1955; "The 'Liberal' Trib," Newsweek, July 2, 1973, p. 50 .

2 "Colonel Was a Man of Many Careers," New York Times, April 1, 1955; "Doesn't Deserve Much," Newsweek, March 8, 1954, p. 74; "Tribune's Colonel Dies," Life, April II, 1955, p. 47.

${ }^{3}$ John A. Tebbel, An American Dynasty (Garden City, New York: Doubleday and Co.. 1947), p. 30; "Thru is Through and So is Tho," Chicago Tribune, Sept. 29, 1975.

4 Robert McCormick, "Behind Four Holiday Cards," Chicago Magazine. Feb. 6, 1955, p. 25; "When Three Bosses Fill One Vacant Chair," Business Week, May 19, 1956, pp. 85, 89-90.

${ }^{5}$ Guido H. Stempel, 111, "Content Analysis" in Research Methods in Mass Communication (Englewood Cliffs, N.J.: Prentice-Hall, Inc. 1981), pp. 119-131; Stempel, "Sample Size for Classifying Subject Matter in Dailies," Journalism Quarterly, 29:333-34 (Summer 1952).

- Geographical emphasis of each editorial was classified into one of the following categories: 1) local - an editorial on a topic within the city of Chicago or the greater Chicago area; 2) statean editorial on an Illinois topic outside of the greater Chicago area, including politics at the state level; 3) national-an editorial commenting on the United States, rather than Illinois or a foreign country; 4) national-international-an editorial involving the United States with another foreign country; and 5) international -an editorial focusing only on a foreign country without any mention of United States involvement.

7 For coding the purpose of each editorial, three categories suggested by Hillier Krieghbaum were used. These are: 1) informative - an editorial presenting facts to help clarify an event or issue without demanding action. This type of editorial also has been called interpretive, explanatory or expository; 2) argumentative - an editorial constructed to persuade the reader toward a particular point of view. All editorials demanding some kind of action or attempting to gain support for a particular viewpoint by persuasion were included in this category; and 3 ) miscellaneous - an editorial that sought to amuse, amaze or entertain readers, but did not give the impression of being either informative or argumentative. Entertainment is the principal goal of this editorial type. See: Hillier Krieghbaum, Facts in Perspective (Englewood Cliffs: Prentice-Hall, 1956), pp. 150257.

8 The subject of each editorial was coded into the following categories used by Paul Deutschmann: politics and gover nment, war and defense, economic activity, crime, public moral problems, public health and welfare, accident and disaster, science and invention, education, popular amusements, and human interest. For clarification, the public moral problems category was distinguished from the public health and welfare category by its emphasis on human relations problems and legal and court actions. The public health and welfare category included only personal or community issues before legal or court action was necessary. Citizens' general welfare dominated this catcgory. See: Paul Deutschmann, News-Page Content of Twelve Metropolitan Dailies, report of a study sponsored by Scripps-Howard Research, October 1959, pp. 58-62.

9 Each editorial was also classified as to its major focus or emphasis, people, issue, or institution. successors because they understood the principles, policies, and ideals of the Tribune. ${ }^{4}$ The subsequent change of editorial authority to William $\mathrm{D}$. Maxwell in 1955 and then to Clayton Kirkpatrick in 1968 raises some questions as to how much the editorial policy changed with each new editor. That is, did the editorial patterns in the Tribune vary with each editor?

Thus, the purpose of this study was to describe and to compare the similarities and differences in editorial patterns in the Tribune during the editorships of McCormick, Maxwell, and Kirkpatrick. Another purpose was to determine the issues stressed by each editor.

\section{Method}

Editorials were selected from the month of April for three time periods of four years each. ${ }^{5}$ Each period represented a different editor: McCormick (1951-54), Maxwell (1965-68), and Kirkpatrick (1976-79). The first two periods represent the last four years completed by McCormick and Maxwell. Sunday editions of the Tribune were also included in the sample.

In this study, an editorial was defined as an unsigned opinion column which reflected the Tribune's views on an issue or event that appeared daily in approximately the same place on the editorial page or section. Each editorial was classified by its geographical emphasis, ${ }^{6}$ purpose, ${ }^{7}$ subject, ${ }^{8}$ focus, ${ }^{9}$ and period. Intercoder reliability on 202 editorials from the three periods was +.862 .

\section{Results}

Table 1 shows that editorials in the Tribune varied considerably with each editor, and these variations were statistically significant. Editorials of the McCormick period focused both on persons $(45.9 \%)$ and on issues ( $41.8 \%$ ), while the Maxwell era stressed mainly issue-oriented $(73.6 \%)$ editorials. In the Kirkpatrick period, the

- John W. Windhauser is an associate professor in the School of Journalism at Louisiana State University. Will Norton, Jr., is an associate professor in the Department of Journalism at the University of Mississippi. Sonny Rhodes is an editorial writer for the Log Cabin Democrat, Conway, Arkansas. 
TABLE 1

Percentage of Editorials in the Chicago Tribune by

Focus, Geographical Emphasis, Purpose, and Subject in Three Editorial Eras

Focus

Persons

Issues

Institutions
Editorial Eras

$\begin{array}{ccc}\begin{array}{c}\text { Editorial Eras } \\ \text { McCormick }\end{array} & \begin{array}{c}\text { Maxwell } \\ (\mathrm{N}=451)\end{array} & \begin{array}{c}\text { Kirkpatrick } \\ (\mathrm{N}=445)\end{array} \\ 45.9 \% & 17.1 \% & 28.8 \% \\ 41.8 & 73.6 & 55.5 \\ 12.3 & 9.3 & 15.7\end{array}$

$\mathrm{X}^{2}=112, \mathrm{df}=4, \mathrm{p}<.0001, \mathrm{~V}=.20, \mathrm{C}=.27$

Geographical Emphasis

Local

State

National

National/International

International

10.2
14.2
37.4
35.5
2.7

8.6

21.1

15.3

39.8

20.9

2.9

$X^{2}=60.7, d f=8, p<.0001, V=.148, C=.20$

Purpose

Informative

Argumentative

Miscellaneous

47.8

72.7

21.6

4.2

5.7

52.6

45.2

2.2

$X^{2}=81.6, d f=4, p<.0001, V=.172, C=.236$

Subject

Politics \& Govt. Acts

War, Rebellion \&

Defense

Economic Activity

Crime

Public Moral Problems

Public Health Problems

Accidents \& Disasters

Science \& Invention

Education

Popular Amusements

General Human Interest
53.0

19.5

37.5

23.2

5.4

2.1

1.3

4.2

.8

.2

1.3

3.5

5.0
20.2

16.4

5.5

8.1

6.4

1.7

1.2

9.3

6.7

5.2
13.3

11.5

3.1

8.5

9.2

.4

.4

9.0

3.6

3.4

$\mathrm{X}^{2}=201.6, \mathrm{df}=20, \mathrm{p}<.0001, \mathrm{~V}=.266, \mathrm{C}=.356$

proportion of issue-oriented editorials decreased significantly from the Maxwell era, while the proportion of personfocused editorials significantly increased.

As for geographical emphasis, the focus was on state and local topics during the Kirkpatrick period. Editorial topics in the McCormick era emphasized national (37.4\%) and national-international (38.2\%) topics, but in the Maxwell period a significantly higher proportion of editorials focused only on national subjects.
The McCormick and Kirkpatrick periods tended to stress both argumentative and informative editorial topics. The Maxwell period differed significantly by having a higher proportionate use of informative editorials. Miscellaneous editorial styles accounted for only a small proportion of topics in all three periods, and most of those were on human-interest subjects.

One interesting point is that editorials in the Kirkpatrick period had the highest proportion of both informative and argumen- 
tative editorials on state and local subjects than were found in either the Maxwell or McCormick sample. By contrast, informative editorial topics in the McCormick era dealt with national or nationalinternational topics, and argumentative editorial styles were fairly well divided as to geographical focus. Only in the Maxwell sample was there a heavy use of both informative and argumentative styles for national topics.

Table 1 also shows these three editors differed greatly in the proportion of editorials for the 11 subjects areas. For example, $53 \%$ of the editorials in the McCormick sample focused on politics and government acts, compared with less than $20 \%$ in the Maxwell period. Both Maxwell and Kirkpatrick used more economic subjects, $16.4 \%$ and $11.5 \%$, than did McCormick, $5.4 \%$.

Although the three editors differed significantly as to the proportion of editorials on selected subject areas, they were quite similar to each other in the rank-order emphasis given the 11 topics. This similarity was indicated by the high rank-order correlations among the editors. The correlations between McCormick and Maxwell were $+.707,+.814$ between McCormick and Kirkpatrick, and +.916 between Maxwell and Kirkpatrick.

\section{Discussion}

The data obtained in this study reveal several different content patterns for the

\footnotetext{
10 Robert A. Rothman and Donald W. Olmsted, "Chicago Tribune Cartoons During and After the McCormick Era," Journalism Quarterly, 43:67-72 (Spring 1966).

" Guido H. Stempel, 11I, "Types and Topies of Editorials in U.S. Dailies," Newspaper Research Journal, prototype edition, April, 1979, pp. 3-6.

12 John W. Windhauser, "Content Patterns of Editorials in Ohio Metropolitan Dailies," Journalism Quarterly. 50:562-567 (Autumn 1973).

${ }^{13}$ Norval Neil Luxon, ${ }^{43,206}$ Newspaper Editorials Studied," Editor \& Publisher, April 11, 1936, pp. 7, 42.

14 Stempel, op. cit.

${ }^{15}$ Ralph R. Thrift Jr., "How Chain Ownership Affects Editoial Vigor of Newspapers," Journalism Quarterly, 54:327-331 (Summer 1977).

10 Kenneth Cushman, "Editorials in Oregon Have Much in Common," Journalism Quarterly. 29:70-2 (Winter 1952); Stempel, op. cit.; Edgar Powell Trotter III, "A Content Analysis of the Editorials of the Nine Largest Kentucky Daily Newspapers." unpublished master's thesis, Ohio University, 1967; Windhauser, $o p$. cit
}

three editors of the Tribune and for editors in general. This study strongly indicates that significant differences occurred in the editorial patterns of the Tribune with each successive change of editor, regardless of the personal philosophy advocated by his predecessor. Editorial cartoons, however, maintained the continuity. ${ }^{10}$ For instance, McCormick, known for his style of personal journalism, felt more strongly about the subjects on which he wrote than did his successors; he used a heavy, peopleoriented and argumentative editorial style. During the Maxwell period, nearly threefourths of the editorials were about issues, but in the Kirkpatrick period following, the proportion of issue-oriented editorials decreased significantly while the proportion of people-oriented editorials increased, although not to the level of the McCormick period.

It is interesting to note the proportion of argumentative or persuasive editorials under McCormick's editorship went from a fairly high percentage to a lower one under Maxwell with a return to a high percentage under Kirkpatrick. Although editorials about national activities dominate all three periods, only during the Kirkpatrick period did the proportion of local editorials increase from one-tenth, under both McCormick and Maxwell, to one-fifth. An almost identical pattern was found in the use of persuasive editorials on local topics.

Similar one-fifth proportions for editorials with a local emphasis were reported by Stempel "t and by Windhauser. ${ }^{12}$ And a slightly higher percentage was found by Luxon in $1936 .{ }^{13}$ Another one-fifth proportion for persuasive, local editorials was similar to the distributions found by Stempel14 for metropolitan dailies and by Thrift ${ }^{15}$ for non-chain newspapers. The high use overall of persuasive editorials by McCormick and Kirkpatrick also reflects a consistent pattern of editorial writing found in other editorial studies. ${ }^{16}$

Another consistent pattern among all three Tribune editors is the emphasis on politics or war and defense subjects. Much of this can be explained by the Tribune's long-time interest in foreign affairs and 
national politics. These two topic categories are also the major ones found in other editorial studies. ${ }^{17}$ In the final analysis, this study provides some evidence that the geographical and persuasive positions of a newspaper's editorials change considerably with each new editor, even though subject areas from editor to editor may receive the same priority.

17 Milton and Hortense Gabel, "Texas Newspaper Opinion: 1," Public Opinion Quarterly, 10:55-70 (Spring 1946); Hillier Krieghbaum, "Editorial Viewpoints Alike in N.Y. and S.F.", Editor \& Publisher, pp. 46,50; Trotter, op. cit.; Windhauser, op. cit. 